\title{
Mineralogy, geochemistry, and genesis of glauconite mineral from paleotsunami deposit in Lebak, Banten, Indonesia
}

\author{
Rasis Abi Tiyana ${ }^{1 *}$, Supriyanto ${ }^{2}$, Tri Rani Puji Astuti ${ }^{1}$, Gamma Abdul Jabbar ${ }^{1}$, and Muhammad Rizqy Septyandy ${ }^{1}$ \\ ${ }^{1}$ Geology Study Program, University of Indonesia, Pondok Cina, Beji, Depok, 16424, Indonesia \\ ${ }^{2}$ Geophysics Study Program, University of Indonesia, Pondok Cina, Beji, Depok, 16424, Indonesia
}

\begin{abstract}
Bagedur coast in Lebak regency, Banten province, Indonesia is part of lowland-swampy swale area that consist of various sediment deposit. Based on its sediment characteristics and geomorphology profile, Bagedur coast is assumed as depositional environment of paleotsunami deposit. Hand Auger drilling method is used to collecting loose sediment sample from eight observation stations. The depth of hand drilling in BG 01 station to BG 08 station is consecutively as follows: $115 \mathrm{~cm}, 100 \mathrm{~cm}, 80 \mathrm{~cm}, 700 \mathrm{~cm}, 400$ $\mathrm{cm}, 450 \mathrm{~cm}, 160 \mathrm{~cm}$, and $143 \mathrm{~cm}$. This research is carried out to understand the diagenetic process of glauconite mineral in presumption paleotsunami deposit. The diagenetic process of glauconite mineral is identified based on its mineralogical and geochemical characteristics by petrography and X-Ray Fluorescence (XRF) methods. Observation samples is taken from green sand sediment bed in hand drilling core. Petrographic analysis under polarized microscope shows various glauconite mineral which recognized as matrix, oval pellets, replacement of precursor mineral, and bioclastic shell infillings. XRF analysis result show that glauconite in observation site are classified as glauconitic-illite type. The diagenetic stage is interpreted as early stage of diagenetic (nascent) which characterized by low $\mathrm{Fe}_{2} \mathrm{O}_{3}$ and $\mathrm{K}_{2} \mathrm{O}$ content relative to $\mathrm{Al}_{2} \mathrm{O}_{3}$ content.
\end{abstract}

\section{Introduction}

Bagedur coast and its surroundings are an area composed by various sedimentary deposits which some of them comes from the marine environment deposited in alluvium units. Geomorphologically, this area is categorized as a lowland which is characterized by geomorphological units of coastal embankment, ridge, and swale. Based on the composition of the sedimentary material and geomorphological characteristics, this area is assumed to preserve paleotsunami deposits [16]. In addition to the presence of swamps which formed in low-land areas, sediment layers that are presumed as paleotsunami deposits can be identified through the presence of glauconite minerals in the hand drilling core.

Sediment layers which contain glauconite will tend to show a greenish colour in the hand drilling core. Glauconite can be used as stratigraphic marker of marine deposits because the formation of glauconite will take place specifically in the marine environment [15]. The depositional environment of glauconite is strongly influenced by the presence of a semi-confined microenvironment. Semi-confined microenvironment is a partially isolated depositional environment with a semi-closed system which able to provide ionic exchange to occur at medium rate [14]. In that condition, glauconite pellets will perform ion exchange from its surrounding environment to increase its maturation to become fully-evolved glauconite.
Glauconite has macroscopic characteristics in the form of spherical peloids in sediments, sandstones, and carbonates with a green oval appearance [15]. Glauconite will undergo morphological deformation through several stages of evolution. There are four stages of glauconite evolution which explain its diagenesis process, they are: nascent, slightly-evolved, evolved, and highly-evolved. The evolution stages of glauconite will indicate the time of glauconite grains spent in seawater-sediment interface zone, which later can be used as indication of sedimentation rate in those facies [5]. The presence of glauconite in hand drilling core taken from the swamp in the swale area can lead us to a presumption of the presence of paleotsunami deposits at those areas.

In this research, the authors conduct sediment sampling around Bagedur Coast, Lebak, Banten on alluvium deposits, especially in swampy areas by HandAuger drilling method Figure 1. This research is carried out because there are still few studies about the diagenesis of glauconite minerals in the sediment layers of presumed tsunami deposit. Glauconite samples were taken from the green sediment layers on the hand drilling core. The sample will then be analysed for its mineralogy and geochemical properties using petrography and X-Ray Fluorescence (XRF) methods. Based on the results from those methods, the mineralogical and geochemical characteristics of glauconite could be recognized, thus it can be used to

\footnotetext{
* Corresponding author: rasisabitiyand@gmail.com
} 


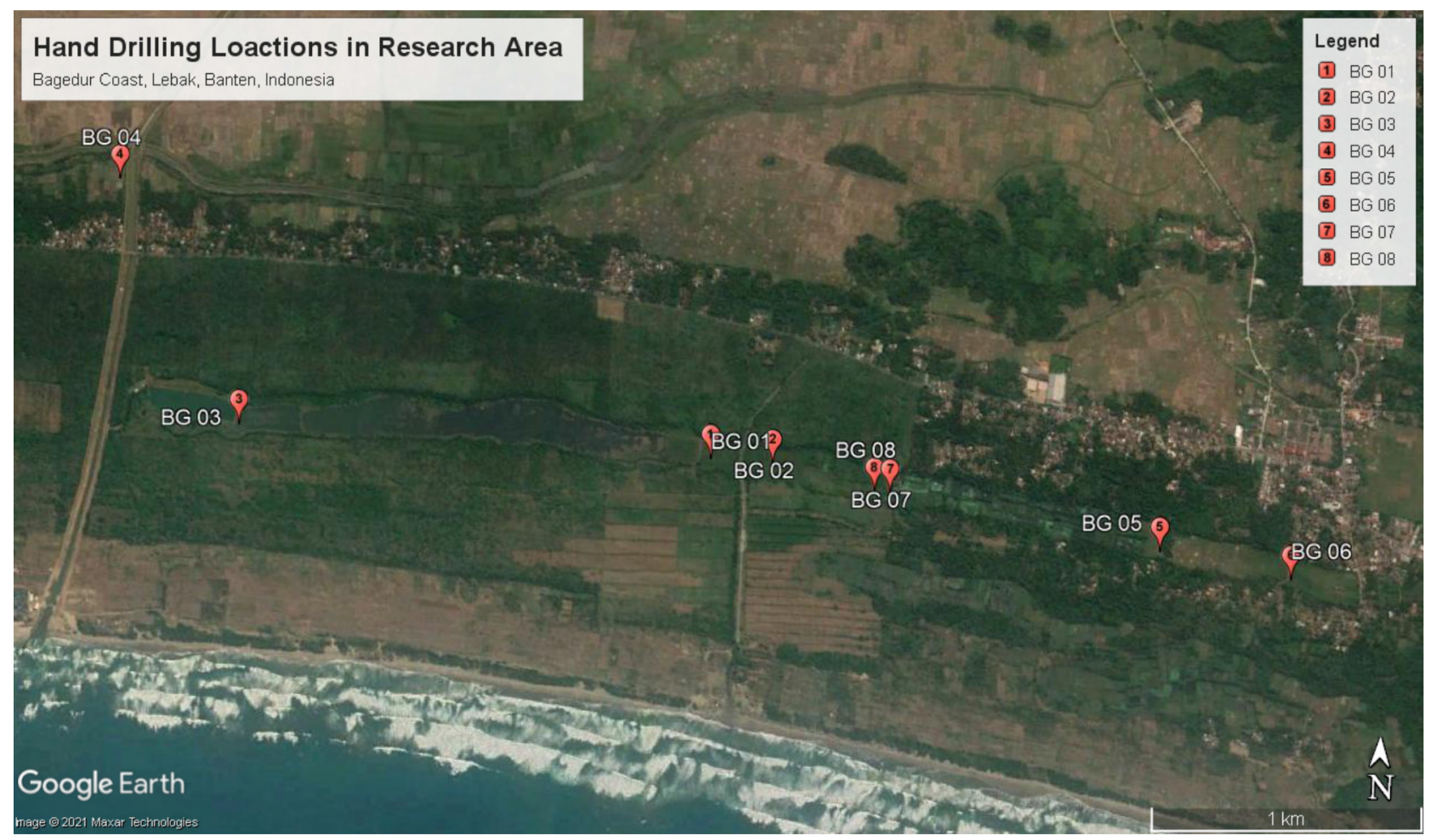

Fig. 1. Research location

explain the diagenesis and depositional process of glauconite at the research area.

\section{Geological settings}

Based on the division of physiographic zones of West Java, the research location is included in the Dome and Mountains section of the Central Depression Zone in the Bayah Mountains. Bayah Mountains is located at south of Banten, extending from Ujung Kulon in the west to Pelabuhan Ratu in the east. Bayah Mountains is formed at Eocene age which consists of a strongly folded area at the southern part of old andesite rocks and the northern part at the central area of the Bogor zone. Bayah area and its surroundings are part of the Sundaland margin of West Java and Oligocene magmatic arc [20].

The geomorphology of the Banten region is generally divided into three groups, namely plain morphology, moderately sloping hills (low-moderate waves) and steep hills. Lowland morphology is generally found at the northern and southern parts. The plains area is formed by an area that has an altitude of less than $50 \mathrm{~m}$ above sea level and a coastal area with altitude of 0-1 $\mathrm{m}$ above sea level. Sampling locations in Bagedur Coast has a geomorphological characteristic of swale in lowlands area. Sediment sampling is focused on swamps zone with loose soil sediment in order to gain greater depth from hand drilling penetration. The location with these geomorphological features is formed with low endogenous and exogenous energy, especially in the process of sediment accumulation in the swamp environment. These conditions will help us to identify sediment deposition anomalies that may occur, such as the occurrence of sediment layers with coarse grains among sediment layers with finer grains in a swamp environment that has low depositional energy.

The research area includes Alluvium (Qa) and Coastal Step (Qc) deposits which formed at Holocene age on the Regional Geological Map of Cikarang on 1:100,000 scale [19]. Those two units are composed of sediments of gravel, sand, silt, clay, silt, and pumice gravel. Furthermore, biogenic compositions were also found in the form of shell fragments and carbonate sediments.

Based on previous researches, there are two presumed paleotsunami deposits in the Banten, which took place at Wanasalam Coast, Wanasalam Region, Banten [21], and Lebak Beaches, Banten [16]. The paleotsunami deposits in those area was located in lowland geomorphology units in the form of swamps, rice fields, and plantations around the coastal area. Sediment deposits that thought to be formed due to the past tsunami process at the coast of Wanasalam, Banten, have characteristics of very fine grain size, poor grain sorting, low organic material content, and relatively higher carbonate material [21]. Meanwhile, the characteristics of the sediments in paleotsunami deposits at the Lebak Beaches show erosional contacts with a finer grain size pattern (fining upward) with poor grain sorting [16]. Foraminifera microfossils were also found in the sediment layer. The paleotsunami deposits which found in the Lebak beach is interpreted to have a relationship to a large-scale earthquake that hit the southern part of Java with a magnitude of more than 9 Mw which occurs every 600 years [11]. 


\section{Methods}

Sampling method for collecting loose sediment sample in the field is carried out by Hand Auger drilling method Figure 2. Hand Auger drilling instrument consists of several steel rods which can be installed at the end of each other rods. The rods are used as both drill bits and drill core container that will be penetrated into the ground and then rotated in order to collect sediment sample in the borehole. Hand Auger steels can be stacked consecutively until it reaches certain depth in the borehole. After we drilled sediment layers out from the soil, we then move it to pipes which used as sample container.
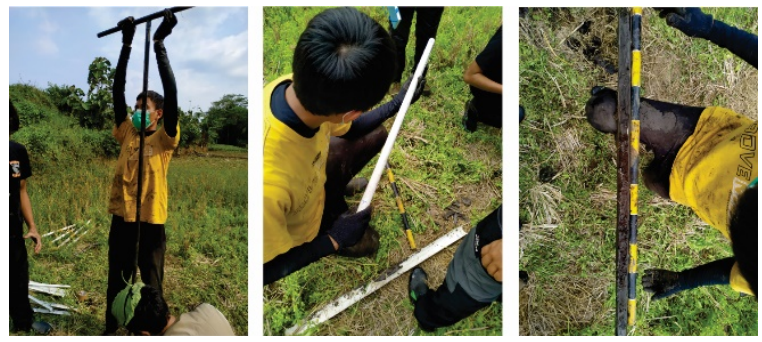

Fig. 2 Hand-Auger drilling method.

There are 8 sampling locations in the research area. The depths of hand drilling from BG 01 station to BG 08 are consecutive as follows: $115 \mathrm{~cm}, 100 \mathrm{~cm}, 80 \mathrm{~cm}$, $700 \mathrm{~cm}, 400 \mathrm{~cm}, 450 \mathrm{~cm}, 160 \mathrm{~cm}$, and $143 \mathrm{~cm}$. Among sediment layers in the drilling core, there are several layers of green sand sediment deposit at certain depths which assumed to contain glauconite minerals.

The green sand sediment layers which contain glauconite minerals then are analysed by petrography and XRF methods to recognize their geochemical properties. Petrography analysis is carried out using Leica DM750 microscope with magnification of 10x to 40x. Sample from microscope objective lenses then captured using camera to perform point counting analysis by making grids towards captured sample image.

$\mathrm{XRF}$ analysis is carried out by several steps of preparation. The first step is to pound the sample until it becomes smooth, then put it in a bottle with a volume of $50 \mathrm{ml}$. To ascertain the weight of the sample, the sample is weighed on a scale until it shows the desired value. The sample then filled with distillation water and be put into an ultrasonic dispenser for 30 minutes. After that, the sample will be put into a centrifuge at $1000 \mathrm{rpm}$ for 4 minutes and reprocessed for 30 minutes at a speed of $3000 \mathrm{rpm}$. The results from the second centrifuge process will be put into sample glass.

\section{Results and discussion}

\subsection{Stratigraphy of Bagedur coast}

Loose sediment deposit layer that composes the drill core has varied characteristics. There are some layers of soil and peat soil with brown to blackish grey colour with high water content so that it looks muddy in the drilling core. The grain size of loose sediment in the drill core has a range between clay to medium sand.

There are other sediment components in the sediment layer at the drilling core in the form of wood fragments, shell fragments, and a layer of green sand sediment. Wood fragments were found in peat soil and sediment layers with grain sizes ranging from silt to medium sand at the shallow depth $(0-10 \mathrm{~cm})$ and the greater depth $(540 \mathrm{~cm})$ (Figure. 3 a). Shell fragments were found at BG 04 and BG 06 stations (Figure $3 \mathrm{~b}$ ). Shell fragments at station BG 04 were found at depths of $370-400 \mathrm{~cm}, 430-470 \mathrm{~cm}, 510-540 \mathrm{~cm}$, and 620-680 $\mathrm{cm}$, while shell fragments at station BG 06 were found at depths of $155-190 \mathrm{~cm}, 190-240 \mathrm{~cm}, 245-280 \mathrm{~cm}, 326-$ $390 \mathrm{~cm}$, and $390-440 \mathrm{~cm}$.

Among all sediment layers in the drilling core, several layers of green sediment were found (Figure. 3 c). Those layers indicate the properties of glauconite in hand specimens. Layers of green sand sediment were found at several stations with different depths, they are BG 02 at the depth of $25-35 \mathrm{~cm}$ and $60-65 \mathrm{~cm}$, BG 05 at depth 218-228 cm and 238-240 cm, BG 06 at depth 142$145 \mathrm{~cm}$, BG 07 at depth $93-130 \mathrm{~cm}$, and at depth BG 08 $0-2 \mathrm{~cm}$ and $83-90 \mathrm{~cm}$. The thickness of the green sand sediment layer varies at different stations with a range between $3-37 \mathrm{~cm}$.

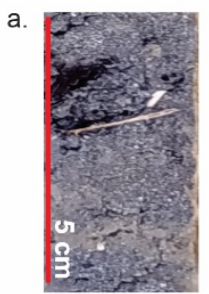

Wood Fragments BG $06(240-245 \mathrm{~cm})$

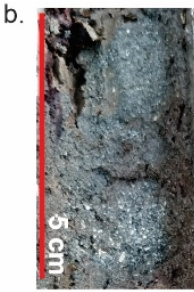

Shell Fragments BG $04(525-530 \mathrm{~cm})$

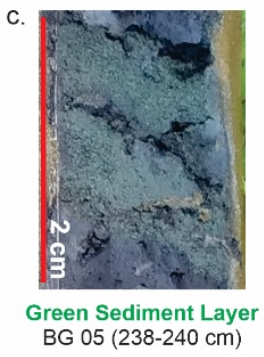

Fig. 3. Sediment components in hand drilling core

Based on the profile of stratigraphic log which taken from swamp environment, stratigraphic correlations are carried out between stations to determine the presence of presumed paleotsunami deposit at the research area. Correlation to indicate paleostunami layers were carried out between green sediment layers which assumed to contain glauconite minerals in it. The correlation result show that presumed paleotsunami layer were found between various layers of green sand sediment at stations BG 02, BG 08, BG 07, BG 05, and BG 06 


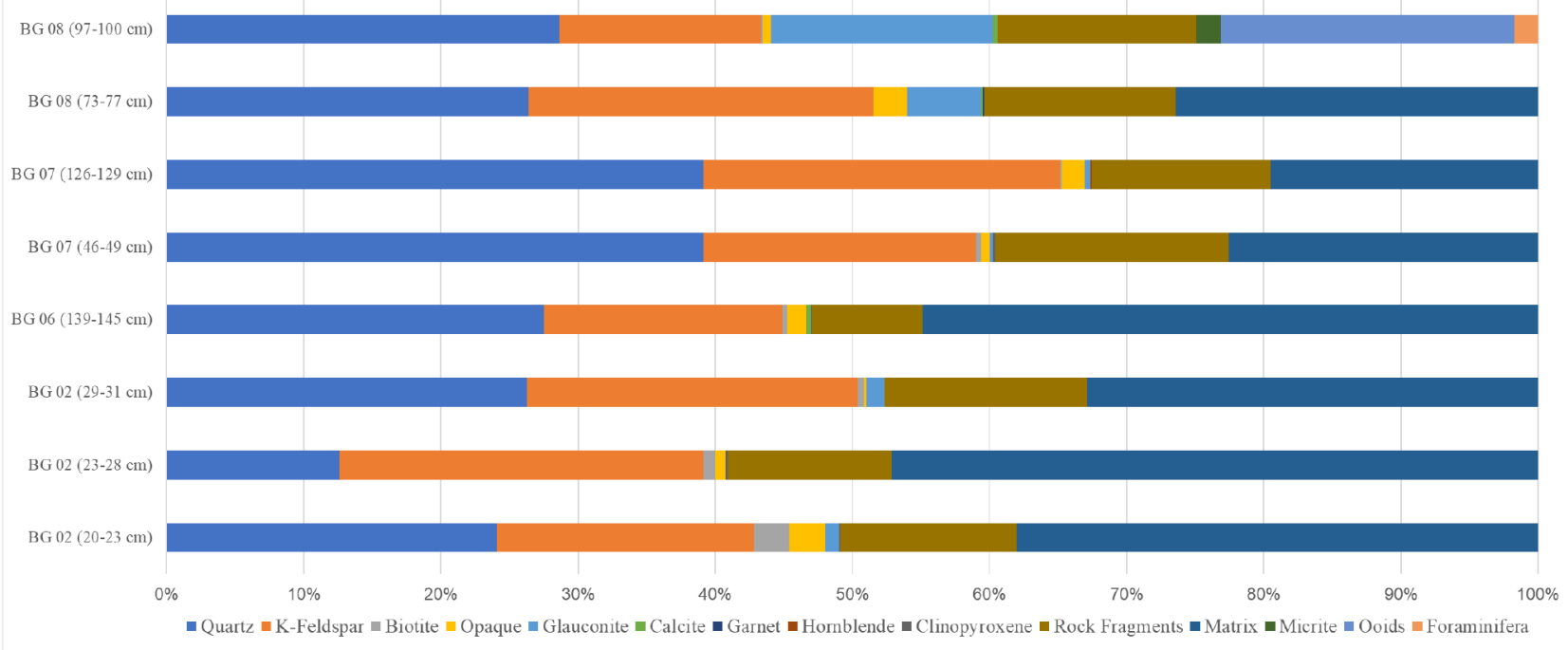

Fig.4. The composition of petrography samples in research area

\subsection{Petrography analysis}

Petrography images were identified using the point counting method at $10 \mathrm{x}$ and $40 \mathrm{x}$ magnifications through parallel and crossed polarization to determine the optical properties and percentage of the minerals and other components (Figure 5). The average number of points counting in each sample is 4417 points from 4 fields of view. Minerals and other constituent components found in petrographic samples include: quartz, k-feldspar, calcite, biotite, opaque, glauconite, garnet, hornblende, clinopyroxene, shell fragments, ooids, foraminifera, rock fragments, and matrix. The result of mineral compositions percentage from point counting method is shown on Figure 4.

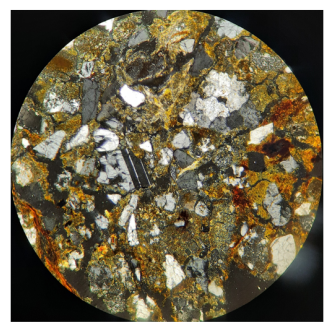

XPL
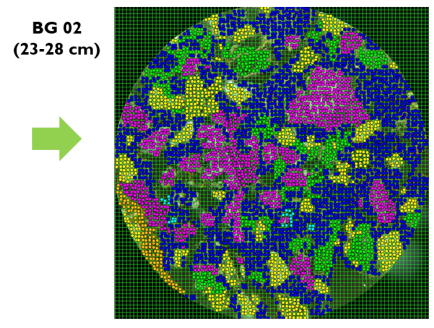

Point Counting
Fig. 5. Point counting in petrography analysis

From the observations, glauconite minerals were found in several samples with various optical properties. Glauconite minerals were found in samples BG 02 at a depth of 20-23 cm, BG 02 at depth of 29-31 cm, BG 07 at depth of 46-49 cm, BG 07 at depth of 126-129 cm, BG 08 at depth of 73-77 cm, and BG 08 at depth 97-100 $\mathrm{cm}$ with an average grain size of $<0.02 \mathrm{~mm}$ and yellowish brown to dark green.

The lowest percentage of glauconite recorded in a thin section has the smallest value of $0.2 \%$ in the BG 07 sample at a depth of $46-49 \mathrm{~cm}$ and the largest percentage value is $16.17 \%$ in the BG 08 sample at a depth of 97$100 \mathrm{~cm}$. Glauconite is found in various forms. They were appeared as a matrix that fills the empty space between minerals (Figure 6 a), rounded oval pellets, replacement of quartz and feldspar minerals, and infillings in shell fragments. The space on the shell fragments was previously a place for the accumulation of sediment and detrital minerals that experienced a change in chemical composition to glauconite minerals, while the outer shell component became a semipermeable barrier that formed a semi-enclosed microenvironment for ion exchange with seawater and surrounding sediments.

\subsubsection{Evolution stage of glauconite}

The petrographic properties from thin sections observations can aid us in making an interpretation about the maturity of glauconite pellets, the type of substrate, and the formation mechanism of glauconite (autochthonous or allochthonous). The Petrographic properties in the aspects of mineral colour, grain shape, and replacement of precursor minerals by glauconite are the most common parameters used in determining the evolutional stages of glauconite [6].

The replacement of glauconite in precursor minerals, especially in fragments of quartz and kfeldspar minerals that appear as rock fragments, are seen in samples BG 02 at the depth of $23-28 \mathrm{~cm}$ and BG 06 at $139-145 \mathrm{~cm}$. Glauconite replacement in sample BG $02(23-28 \mathrm{~cm})$ indicates that the glauconite is entering an early stage of evolution (nascent) (Figure $6 \mathrm{~b}$ ). This stage is indicated by the replacement of glauconite in a rounded oval shape with a bright yellow-green colour which still leaves a small amount of trace from the precursor minerals (K-feldspar). Replacement of 
glauconite at slightly evolved stage is shown in sample BG 06 139-145 cm (Figure $6 \mathrm{c}$ ). At this stage, glauconite replacement will tend to show a dark greenish colour with fewer trace of precursor minerals than the nascent stage evolution [6].

The colour of glauconite minerals that undergo the early stage of evolution (nascent) will tend to show dark yellow to light green colour. The colour of mineral body will be darker green as they processed to the higher stage of evolution [9]. Petrography sample that shows higher colour of evolution stages can be seen in sample BG 07 $(126-129 \mathrm{~cm})$ (Figure $6 \mathrm{~d})$. In addition to the dark green colour, glauconite minerals that have undergone a high evolution stage are also characterized by rounded oval shape, this feature is shown in sample BG 08 (97-100 $\mathrm{cm}$ ) (Figure $6 \mathrm{e}$ ).

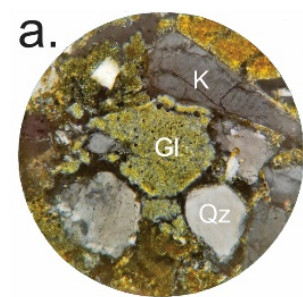

BG $02(20-23 \mathrm{~cm})$

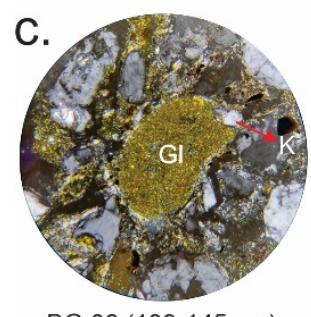

BG $06(139-145 \mathrm{~cm})$

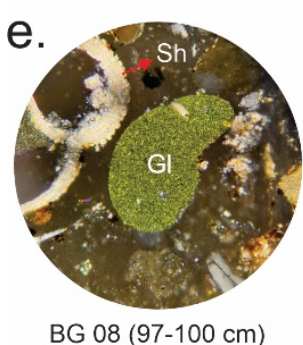

BG $08(97-100 \mathrm{~cm})$

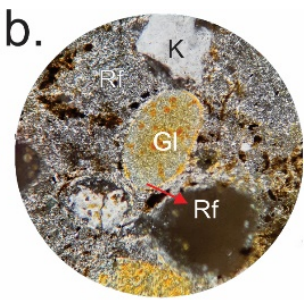

BG $02(23-28 \mathrm{~cm})$

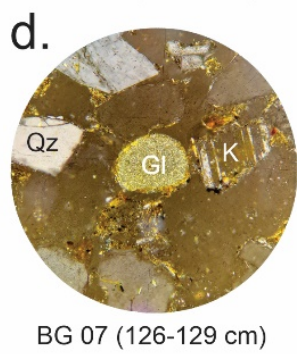

BG $07(126-129 \mathrm{~cm})$

$0.4 \mathrm{~mm}$

Fig. 6 Variations of glauconite form in petrography samples (a. Matrix; b and c. replacement of k-feldspar minerals; d. and e. rounded oval)

\subsubsection{Substrates of glauconite based on petrography characteristics}

Through petrography analysis, we recognized two types of substrates for glauconite evolution processes to take place by its shape characteristics, they are: faecal pellets and bioclastic. Semi-rounded faecal pellets substrate was seen on sample BG 07 (126-129 cm) with a size of $0.1 \mathrm{~mm}$ (Figure $7 \mathrm{a}$ ), and bioclastic substrate can be seen on sample BG $08(97-100 \mathrm{~cm})$ (Figure $7 \mathrm{~b})$. Some of glauconites show an empty pattern on its mineral body which is assumed as the trace of shell

fragment that previously served as bioclastic substrate for glauconite evolution process (Figure $7 \mathrm{c}$ ). Bioclastic substrates will completely disappeared at the early stage of evolution process due to the effect of dissolution process [7].
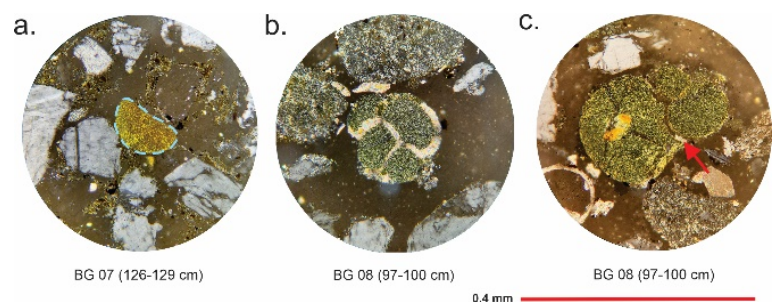

Fig. 7. Variations of glauconite substrates in petrography samples (a. Fecal pellets; b and c. replacement of k-feldspar minerals; $d$. and e. rounded oval)

\subsubsection{Mechanism of glauconite formation}

Glauconite mineral found in the research location is assumed to be the result of transportation from the marine environment to the coastal environment by the tsunami waves. Based on that condition, the formation mechanism process of glauconite can be classified as an allochthonous process. Glauconite minerals which experienced a transportation process from its place of origin (allochthonous) will show petrographic characteristics with good sorting with other components, mineral habits in the form of granules, round grain shape, similarity of grain size with other detrital materials, and lack of fracture features in mineral body [1].

Grain sorting in petrographic samples which contain glauconite mineral shows moderate sorting of grain components. The shape of the glauconite mineral in the thin sections appears as a granular form with a round grain shape without any fracture features on the grain surface. The grain size comparison between glauconite minerals with crystals and other detrital materials in thin sections shows a similar size range that not indicates a significant difference, which is between 0.04-0.2 $\mathrm{mm}$.

\subsection{XRF analysis}

$\mathrm{XRF}$ analysis was carried out on eight samples from stations BG 05, BG 06, and BG 08. Each sample is composed by various compounds with up to 17 different compounds found in one sample. $\mathrm{SiO}_{2}$ became the most dominant compounds in all samples, with the lowest percentage of $\mathrm{SiO}_{2}$ is recorded in sample BG 06 (221$222 \mathrm{~cm}$ ) by $40.7 \%$, and the largest percentage is shown in sample BG $08(41-43 \mathrm{~cm})$ with values up to $75.2 \%$. This result is also match with the result of petrography analysis, where the most abundant mineral found in each sample is quartz with chemical formula of $\mathrm{SiO}_{2}$.

Observations on the chemical composition of each sample are focused on potassium $\left(\mathrm{K}_{2} \mathrm{O}\right)$, iron $\left(\mathrm{Fe}_{2} \mathrm{O}_{3}\right)$, magnesium $(\mathrm{MgO})$, and aluminium $\left(\mathrm{Al}_{2} \mathrm{O}_{3}\right)$. This is because the content of potassium, iron, and aluminium 
can be used to determine the stage of maturity in the stage of glauconite evolution [15].

\subsubsection{Cross-plot correlations}

Based on XRF data interpretations, it can be seen that there is a repeating pattern in most of the samples. The pattern shows that the composition of $\mathrm{SiO}_{2}$ is the most abundant compound in all of the samples, followed by $\mathrm{Al}_{2} \mathrm{O}_{3}, \mathrm{Fe}_{2} \mathrm{O}_{3}, \mathrm{MgO}$, and $\mathrm{K}_{2} \mathrm{O}$ compounds. Quantitative correlation cross-plots between the existing chemical compositions were carried out to determine the effect of the composition of one compound on the composition of other compounds. The correlation is represented in a polynomial regression graph of four pairs of compounds that are compared with each other, they are: $\mathrm{Al}_{2} \mathrm{O}_{3}$ vs $\mathrm{Fe}_{2} \mathrm{O}_{3}, \mathrm{~K}_{2} \mathrm{O}$ vs $\mathrm{Al}_{2} \mathrm{O}_{3}, \mathrm{~K}_{2} \mathrm{O}$ vs $\mathrm{Fe}_{2} \mathrm{O}_{3}$, and $\mathrm{K}_{2} \mathrm{O}$ vs $\mathrm{MgO}$.

The comparison between the pairs of compounds above was carried out to determine the relationship of chemical compound exchanges that occurred during the glauconite evolution process. Chemical compounds that have a major influence in determining the level of glauconite evolution are $\mathrm{Al}_{2} \mathrm{O}_{3}, \mathrm{~K}_{2} \mathrm{O}$, and $\mathrm{Fe}_{2} \mathrm{O}_{3}$. Along with the increase in $\mathrm{K}_{2} \mathrm{O}$ and $\mathrm{Fe}_{2} \mathrm{O}_{3}$ and decrease in $\mathrm{Al}_{2} \mathrm{O}_{3}$ compounds during the maturation process, $\mathrm{MgO}$ compounds will be released during the process of sediment infillings and seawater intrusion into the semiconfined microenvironment [15]. $\mathrm{MgO}$ depletion pattern can also be analysed towards its relationship with $\mathrm{K}_{2} \mathrm{O}$ compounds.

By plotting the composition of chemical compounds between samples on a polynomial regression graph, the value of $r^{2}$ will be obtained which represents the strength or weakness of the influence between two chemical compounds that are compared between each other. Based on the cross-plot results, the correlation between compounds in all graphs shows an intermediate relationship, with a range of $\mathrm{r}^{2}$ values from 0.2968 0.5384 . The polynomial correlation shows a pattern of increasing and decreasing certain compounds from different samples.

The correlation pattern in all of the cross-plot graphs shows a mixed pattern between compared samples. The relationship between $\mathrm{Al}_{2} \mathrm{O}_{3}$ and $\mathrm{Fe}_{2} \mathrm{O}_{3}$ shows a positive correlation from BG 08 stations in the west to $\mathrm{BG} 05$ and 06 stations in the east with $\mathrm{r}^{2}$ value of 0.4839 (Figure 8 a).

Changes in the correlation pattern of $\mathrm{K}_{2} \mathrm{O}$ and $\mathrm{Al}_{2} \mathrm{O}_{3}$ compounds were shown in the samples from BG 08 and 06 with BG 05 (Figure 8 b). The initial pattern showed a positive correlation between samples at BG 05 stations (237-238 cm), BG 06, and BG 08 which then showed a negative correlation. to the sample BG $05(226-228 \mathrm{~cm})$. The $\mathrm{r}^{2}$ value of this correlation is 0.5384 .

The correlation between $\mathrm{K}_{2} \mathrm{O}$ and $\mathrm{Fe}_{2} \mathrm{O}_{3}$ from the analysed samples shows a change in trend which is indicated by the curve pattern (Figure $8 \mathrm{c}$ ). In this correlation, it can be seen that there is a change from a negative correlation between BG 05 and BG 08 which then becomes a positive correlation in BG 06. There is a decrease in $\mathrm{Fe}_{2} \mathrm{O}_{3}$ content and an increase in $\mathrm{K}_{2} \mathrm{O}$ content between sample BG 05 at the depth of $226-228 \mathrm{~cm}$ and $237-238 \mathrm{~cm}$. The $\mathrm{r}^{2}$ value of this correlation is 0.4918 .

The correlation between $\mathrm{K}_{2} \mathrm{O}$ and $\mathrm{MgO}$ also shows a similar pattern to the correlation between $\mathrm{K}_{2} \mathrm{O}$ and $\mathrm{Fe}_{2} \mathrm{O}_{3}$ compounds (Figure $7 \mathrm{~d}$ ). A negative correlation characterized the decrease in compound composition simultaneously at samples from BG 05 and BG 08, which then turned into a positive correlation at samples from BG 06. The $\mathrm{r}^{2}$ of this correlation is 0.5132 .
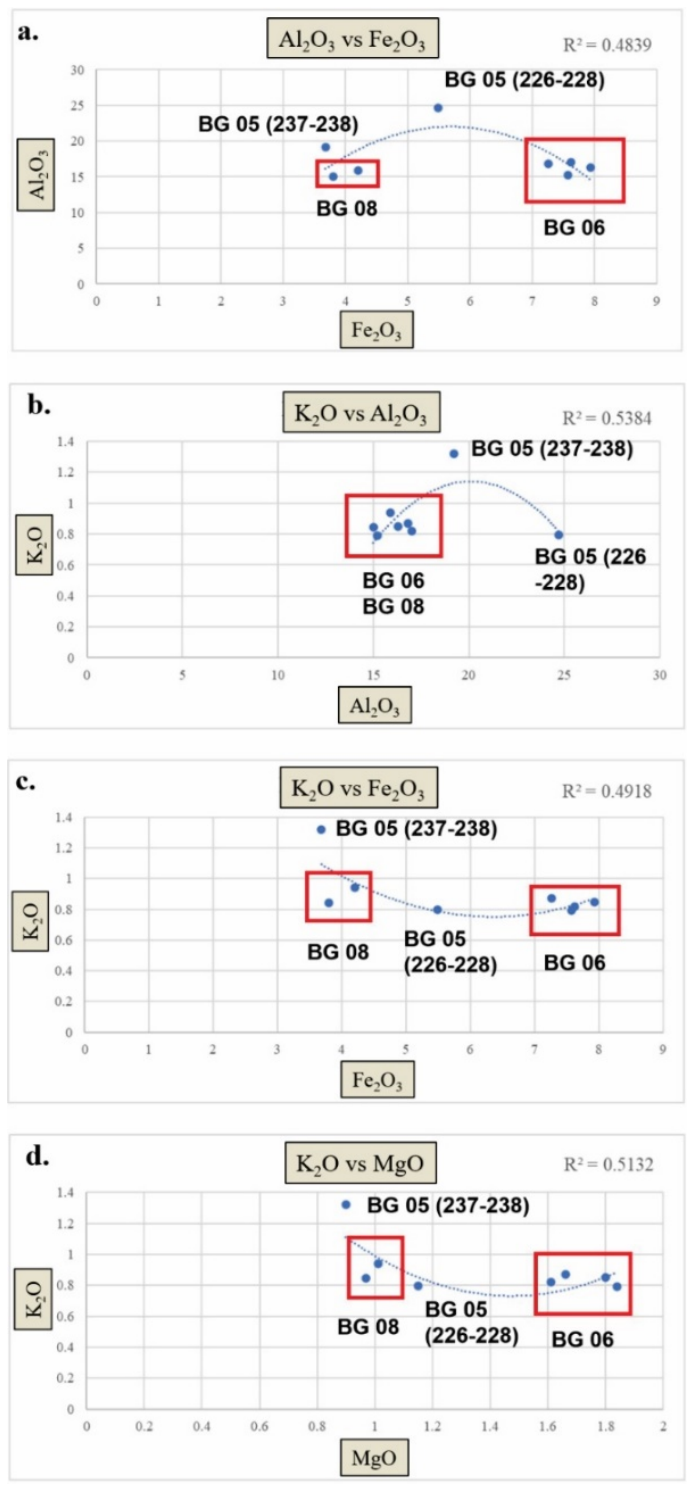

Fig. 8. Cross-plots of chemical compounds in XRF Analysis (a. $\mathrm{Al}_{2} \mathrm{O}_{3}$ vs $\mathrm{Fe}_{2} \mathrm{O}_{3}$; b. $\mathrm{K}_{2} \mathrm{O}$ vs $\mathrm{Al}_{2} \mathrm{O}_{3}$; c. $\mathrm{K}_{2} \mathrm{O}$ vs $\mathrm{Fe}_{2} \mathrm{O}_{3}$; d. $\mathrm{K}_{2} \mathrm{O}$ vs $\mathrm{MgO})$

\subsubsection{Geochemical interpretations}

The increase in the composition of $\mathrm{K}_{2} \mathrm{O}$ and $\mathrm{Fe}_{2} \mathrm{O}_{3}$ occurs when the burial process take place at seawater-sediment interface zone in the semi-confined microenvironment where the supply of both compounds predominantly comes from water and marine sediments [10]. The $\mathrm{K}$ ion in the $\mathrm{K}_{2} \mathrm{O}$ compound also act as interlayer cation that binds the tetrahedral and octahedral sheets on the glauconite mineral structure [2]. This pattern can be 
seen in the correlation graph between $\mathrm{K}_{2} \mathrm{O}$ and $\mathrm{Fe}_{2} \mathrm{O}_{3}$ between samples from BG $05(226-228 \mathrm{~cm})$ and BG 06 .

The decrease in $\mathrm{Al}_{2} \mathrm{O}_{3}$ content is due to the substitution process of $\mathrm{Al}_{2} \mathrm{O}_{3}$ compounds with $\mathrm{Fe}_{2} \mathrm{O}_{3}$ in the octahedral layer of glauconite minerals [12]. As a result of this substitution process, the composition of the $\mathrm{Al}_{2} \mathrm{O}_{3}$ compound will decrease as the $\mathrm{Fe}_{2} \mathrm{O}_{3}$ became more abundant. This substitution process will also affect the crystal structure of the glauconite mineral, where based on the chemical formula of the glauconite mineral $\left[\mathrm{K}_{(x+}\right.$ ${ }_{n}\left(\mathrm{Fe}^{3+}, \mathrm{Al}, \mathrm{Mg}, \mathrm{Fe}^{2+}\right)(\mathrm{OH})_{-2}\left(\mathrm{Si}_{4-x} \mathrm{Al}_{2}\right) \mathrm{O}_{10}$, the $\mathrm{Fe}^{3+}$ content is described as having relatively more abundant composition than Al. The decreasing pattern of this compound is shown in the correlation graph between $\mathrm{Al}_{2} \mathrm{O}_{3}$ with $\mathrm{Fe}_{2} \mathrm{O}_{3}$ and $\mathrm{K}_{2} \mathrm{O}$. The negative correlation on the $\mathrm{Al}_{2} \mathrm{O}_{3}$ vs $\mathrm{Fe}_{2} \mathrm{O}_{3}$ graph is shown by the relationship between sample BG $05(226-228 \mathrm{~cm})$ and sample BG 06, while a negative correlation on the $\mathrm{Fe}_{2} \mathrm{O}_{3}$ and $\mathrm{K}_{2} \mathrm{O}$ graph is shown between sample BG $05(237-238 \mathrm{~cm})$ and sample BG $05(226-228 \mathrm{~cm})$.

Table 1. Comparison between glauconite chemical content in Bagedur coast with [14].

\begin{tabular}{|l|c|c|c|}
\hline Compounds & $\begin{array}{c}\text { Usual } \\
\text { composition } \\
\text { (Odin and } \\
\text { Fullagar, } \\
1988)\end{array}$ & $\begin{array}{c}\text { Composition } \\
\text { in XRF } \\
\text { samples }\end{array}$ & $\begin{array}{c}\text { Criteria } \\
\text { Evaluation }\end{array}$ \\
\hline $\mathrm{SiO}_{2}$ & $\begin{array}{c}47.5-50 \\
\mathrm{wt} \%\end{array}$ & $\begin{array}{c}42-75.2 \\
\mathrm{wt} \%\end{array}$ & Fulfilled \\
\hline $\mathrm{Al}_{2} \mathrm{O}_{3}$ & $\begin{array}{c}3.5-11 \\
\mathrm{wt} \%\end{array}$ & $\begin{array}{c}15-27.7 \\
\mathrm{wt} \%\end{array}$ & Fulfilled \\
\hline $\mathrm{Fe}_{2} \mathrm{O}_{3}$ & $\begin{array}{c}19-25 \\
\mathrm{wt} \%\end{array}$ & $\begin{array}{c}3.68-7.93 \\
\mathrm{wt} \%\end{array}$ & $\begin{array}{c}\text { Not } \\
\text { Fulfilled }\end{array}$ \\
\hline $\mathrm{MgO}^{2} \%$ & $2-5 \mathrm{wt} \%$ & $\begin{array}{c}0.899-1.84 \\
\mathrm{wt} \%\end{array}$ & $\begin{array}{c}\text { Not } \\
\text { Fulfilled }\end{array}$ \\
\hline $\mathrm{K}_{2} \mathrm{O}$ & $3-9 \mathrm{wt} \%$ & $\begin{array}{c}0.791-1.32 \\
\mathrm{wt} \%\end{array}$ & $\begin{array}{c}\text { Not } \\
\text { Fulfilled }\end{array}$ \\
\hline
\end{tabular}

Odin and Fullagar classified typical abundances of major cations which present in glauconitic green grains [14] (Table 1). Based on the analysis result, there were 3 compounds that did not meet the criteria range to be classified as glauconite green grains.

The composition of $\mathrm{K}_{2} \mathrm{O}$ from all samples are 0.9$1.32 \mathrm{wt} \%$, which not meet the minimum value of $3 \mathrm{wt} \%$ in the classification of Odin and Fullagar [14]. The low value of $\mathrm{K}_{2} \mathrm{O}$ is assumed to be caused by the high presence of substrates, especially for the bioclastic substrates. The formation of smectite minerals in the early stages of the evolution of glauconite minerals is thought to be the cause of the low $\mathrm{MgO}$ content. Smectite is formed through the process of replacing sediment grains with $\mathrm{Mg}$ and $\mathrm{Fe}$ ions which decreases the composition of both ions along with the development of smectite minerals [3].
For $\mathrm{Fe}_{2} \mathrm{O}_{3}$, the average percentage of the $8 \mathrm{XRF}$ samples was $5.94 \mathrm{wt} \%$, which again did not meet the minimum criteria of $\mathrm{Fe}_{2} \mathrm{O}_{3}$ content by $19 \mathrm{wt} \%$. The low content of $\mathrm{Fe}_{2} \mathrm{O}_{3}$ is mainly influenced by the presence of an oxic depositional environment [14]. The existence of an oxic depositional environment is caused by the supply of fresh water which causes a decrease in the mobility of $\mathrm{Fe}$ ions, thus making the sample have a low Fe content [2].

\subsubsection{Type of glauconite mineral}

There are two types of glauconite minerals which distinguished by the composition of $\mathrm{K}_{2} \mathrm{O}$ and $\mathrm{Fe}_{2} \mathrm{O}_{3}$, they are illitic minerals (Fe-illite) and glauconite mica (true glauconite) [15]. Based on the cross-plot results, the samples were categorized as illitic minerals with the composition of $\mathrm{K}_{2} \mathrm{O}$ between $0.796-1.32 \%$, and $\mathrm{Fe}_{2} \mathrm{O}_{3}$ between 3.68-7.93\% (Figure 9).

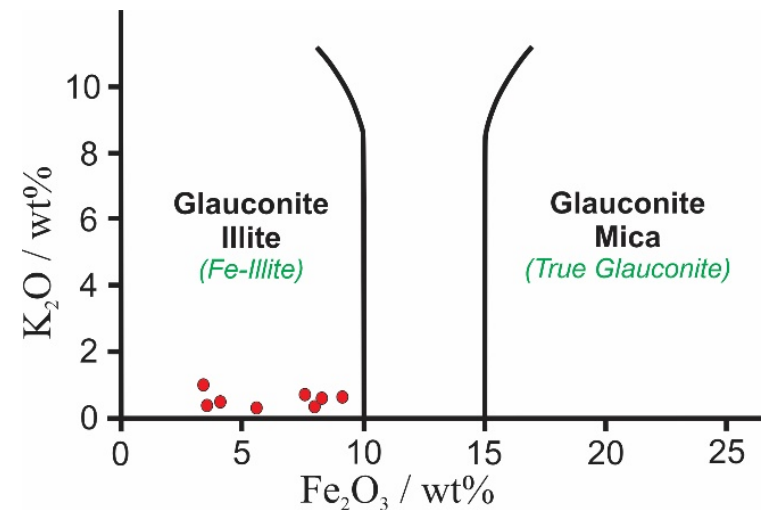

Fig. 9 Types of glauconite based on $\mathrm{K}_{2} \mathrm{O}$ and $\mathrm{Fe}_{2} \mathrm{O}_{3}$ cross-plots

\subsubsection{Substrate of glauconite based on chemical composition}

The bioclastic substrate is assumed as dominant substrate in diagenesis of the glauconite pellets based on XRF analysis result. Bioclastic substrates are characterized by high $\mathrm{Al}_{2} \mathrm{O}_{3}$ content [18], where it was found that the $\mathrm{Al}_{2} \mathrm{O}_{3}$ content from all samples shows a relatively high composition with the value ranging from $15-24.7 \mathrm{wt} \%$. The content of $\mathrm{CaO}$ at sample BG 06 from all depths also shows a relatively high composition with a range between 22.9-25.5 wt\%, where this result is also in line with the finding of bioclastic components in the form of shell fragments in the stratigraphic logs at the same depths.

The bioclastic substrate is also characterized by low content in $\mathrm{Fe}$ and $\mathrm{K}$. The low content of $\mathrm{Fe}$ and $\mathrm{K}$ of bioclastic substrates in all samples relative to the fecal pellets is because fecal pellets have a higher porosity and organic carbon content so that they can support the enrichment of $\mathrm{Fe}$ in glauconite pellets [17].

Bioclastic substrates such as Foraminifera, gastropods, Bryozoa, and Ostracods are porous, but the diameter of the pores are too small $(<5 \mathrm{~m})$, which makes seawater supply and diffusion of seafloor sediments that carry $\mathrm{K}$ and Fe ions into the substrate is restricted [4]. 
The low supply of seawater and seafloor sediment that enters through the pores of microorganisms makes $\mathrm{Fe}_{2} \mathrm{O}_{3}$ and $\mathrm{K}_{2} \mathrm{O}$ levels in XRF samples are low.

\subsubsection{Evolution of glauconite grains}

The composition of $\mathrm{K}_{2} \mathrm{O}, \mathrm{Fe}_{2} \mathrm{O}_{3}$, and $\mathrm{Al}_{2} \mathrm{O}_{3}$ can be used to determine the evolution stages of glauconite minerals. The stages of glauconite evolution were divided into four parts: nascent, slightly evolved, evolved, and highly evolved [14]. The composition of $\mathrm{K}_{2} \mathrm{O}, \mathrm{Fe}_{2} \mathrm{O}_{3}$ and $\mathrm{Al}_{2} \mathrm{O}_{3}$ in all samples can be seen in Table 3. Analysis result shows that all samples undergone an early stage of evolution (nascent) which is characterized by the percentage of chemical composition of $\mathrm{K}_{2} \mathrm{O}$ in less than $4 \%, \mathrm{Fe}_{2} \mathrm{O}_{3}$ content between $8-12 \%$, and $\mathrm{Al}_{2} \mathrm{O}_{\text {s }}$ content between 16-20\% (Fig. 10).

Table 2. Content of major glauconite chemical compounds in samples from Bagedur coast

\begin{tabular}{|c|c|c|c|}
\hline Camples & $\mathbf{K}_{2} \mathbf{O}$ & $\mathrm{Fe}_{2} \mathrm{O}_{3}$ & $\mathbf{A l}_{2} \mathbf{O}_{3}$ \\
\hline BG $05(226-228 \mathrm{~cm})$ & 0.796 & 5.49 & 24.7 \\
\hline BG $05(237-238 \mathrm{~cm})$ & 1.32 & 3.68 & 19.2 \\
\hline BG $06(221-222 \mathrm{~cm})$ & 0.791 & 7.57 & 15.2 \\
\hline BG $06(240-242 \mathrm{~cm})$ & 0.849 & 7.93 & 16.3 \\
\hline BG $06(249-251 \mathrm{~cm})$ & 0.871 & 7.26 & 16.8 \\
\hline BG $06(436-437 \mathrm{~cm})$ & 0.819 & 7.62 & 17 \\
\hline BG $08(0-2 \mathrm{~cm})$ & 0.94 & 4.2 & 15.9 \\
\hline BG $08(41-43 \mathrm{~cm})$ & 0.844 & 3.8 & 15 \\
\hline
\end{tabular}

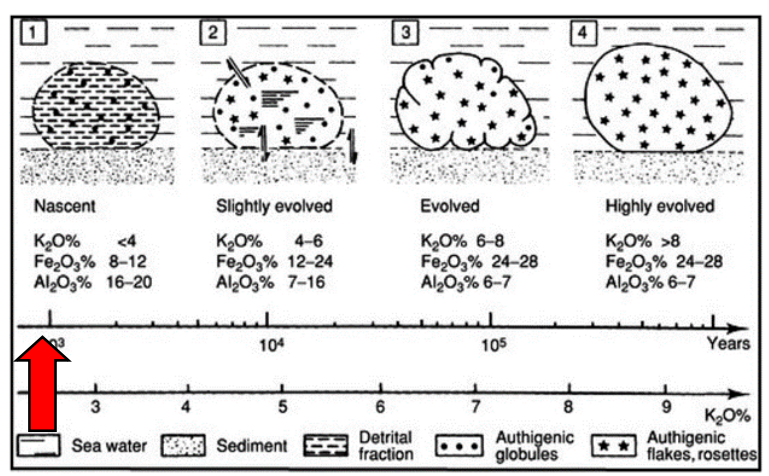

Fig. 10 Major chemical composition plot on glauconite evolution diagram by [15]

The evolution of glauconite pellets was significantly controlled by the sedimentation rate and the physical characteristics of the substrate in the form of porosity and permeability [19]. The condition of the porous and permeable substrate supports the enrichment of $K$ and Fe compounds that enter from the environment around the substrate, and a low sedimentation rate is also needed to enable stable condition for glauconite maturation to not disturbed by the accumulation of large amounts of terrigenous material.

\subsection{Diagenesis process of glauconite}

The diagenesis of glauconite minerals at the research area follows the "Verdissement" theory [15] (Figure 11). Glauconite formed from oxidation process of organic material and the exchange of compounds between the substrate and the surrounding environment in a semiconfined microenvironment. The process of glauconite evolution occurs in the seawater-sediment interface in seafloor. Oxidation of organic material supported by the redistribution of sediment by bottom-current winnowing. Sub-oxic and semi-confined microenvironment conditions are then formed through the process of decomposition of organic material from faecal pellets and microfossil shells substrates [4].

There is an infilling of detrital material from loose sediments and mineral debris into the pores of the substrate which will change the composition of chemical compounds in advanced process due to contact with seawater. Fe-Al smectite then formed by rapid crystal growth process in detrital phyllosilicates minerals in response of changes in chemical [15, 13]. The duration of $\mathrm{Fe}-\mathrm{Al}$ smectite formation is limited by the rapid sedimentation rate, where the presence of $\mathrm{Fe}$ Al smectite will then be replaced by a further evolutionary process into Fe-illite or glauconite mica.

Chemical composition change in semi-confined microenvironment cause the dissolution of the substrate until it be removed completely [7]. The dissolution of the bioclast substrate at the research area was encountered in samples BG $07(126-129 \mathrm{~cm})$ and BG 08 $(97-100 \mathrm{~cm})$ which left glauconite in an empty space in the shell.

Ions from the surrounding environment of the substrate will affect the chemical composition of the glauconite. $\mathrm{Al}$ and $\mathrm{K}$ ions are predominantly supplied by seawater, while $\mathrm{Fe}$ ions come from the diffusion process from sediment deposits at the seafloor [4]. Dissolution of the substrate will release chemical compounds, such as the faecal pellets that supplies $\mathrm{Fe}$ and $\mathrm{K}$ ions [2].

$\mathrm{Fe}-\mathrm{Al}$ smectite will then turned into Fe-Illite or glauconite mica by increasing the number of $\mathrm{Fe}$ ions through a chemical diffusion process. At the research area, glauconite shows a tendency to grow as illitic minerals (Fe-illite) based on the analysis of $\mathrm{Fe}_{2} \mathrm{O}_{3}$ content which has a low value $(<10 \mathrm{wt} \%)$. The process of glauconite evolution at the research area is ended at the nascent evolutionary stage. 
1. Formation of Semi-confined Microenvironment Semi-confined microenviroment were formed at transgression phase when the sedimentation rate is low. There are various ions and compounds which support the early stage of glauconitization in this condition.
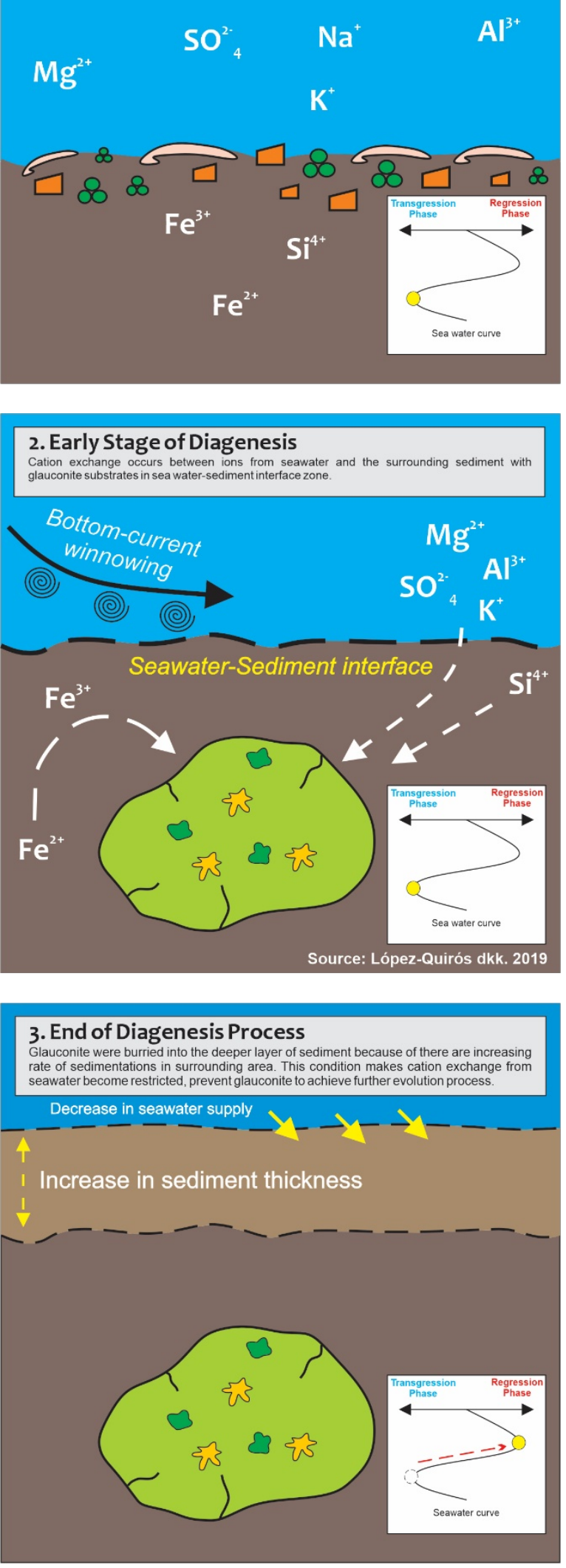

Fig. 11 Diagenesis process of glauconite in Bagedur Coast

\section{Conclusions}

Based on the results of geochemical and mineralogical analysis using petrography and XRF methods, we got several conclusions about the characteristics of glauconite in research area, they are:

1. The types of sediment in research area are composed by soil, peat soil, clay, silt, very fine sand to medium sand, and a layer of green sand sediment. There are also other components in the form of wood fragments, detrital minerals, and shell fragments between sediment layers at several sampling stations with varying depths.

2. Glauconite were found in green sand sediment layers at 5 stations: BG 02, BG 07, BG 08, BG 05, and $\mathrm{BG}$ 06. Glauconite has petrographical properties of greenish yellow to dark green colour with various shapes, appearing as a matrix, ovalshaped pellets, replacement of precursor minerals, and infillings of voids in shell fragments.

3. The geochemical properties of glauconite indicates that they are entering the early stage of evolution (nascent). Glauconite shows characteristics as an illitic mineral. The composition of primary chemical compounds is same in all samples. They have relatively higher $\mathrm{Al}_{2} \mathrm{O}_{3}$ content than $\mathrm{Fe}_{2} \mathrm{O}_{3}$ and $\mathrm{K}_{2} \mathrm{O}$.

4. The formation of glauconite in research area follows Verdissement mechanism (Odin and Matter, 1981), where glauconite form a semi-confined microenvironment through their interactions with the substrate, seawater and surrounding sediments. Glauconite then undergoes an evolutionary process through the exchange of chemical compounds and stopped at the nascent stage.

The limitation of this research is we only focus about the analysis of glauconite diagenesis in paleotsunami deposit. For further interpretation about the tsunami source, radiometric dating method should be conducted to answer those question.

\section{References}

1. Amorosi, A. Detecting compositional, spatial, and temporal attributes of glaucony: a tool for provenance research. Sedimentary Geology, 109(12), 135-153 (1996)

2. Amorosi, A., Sammartino, I., \& Tateo, F. Evolution patterns of glaucony maturity: a mineralogical and geochemical approach. Deep Sea Research Part II: Topical Studies in Oceanography, 54(11-13), 13641374 (2007)

3. Amorosi, A., Guidi, R., Mas, R., \& Falanga, E. Glaucony from the Cretaceous of the Sierra de Guadarrama (Central Spain) and its application in a sequence-stratigraphic context. International Journal of Earth Sciences, 101(2), 415-427 (2012)

4. Banerjee, S., Chattoraj, S. L., Saraswati, P. K., Dasgupta, S., \& Sarkar, U. Substrate control on formation and maturation of glauconites in the Middle Eocene Harudi Formation, western Kutch, 
India. Marine and Petroleum Geology, 30(1), 144160 (2012)

5. Banerjee, S., Bansal, U., \& Thorat, A. V. A review on palaeogeographic implications and temporal variation in glaucony composition. Journal of Palaeogeography, 5(1), 43-71 (2016)

6. Bansal, U., Banerjee, S., Ruidas, D. K., \& Pande, K. Origin and geochemical characterization of the glauconites in the Upper Cretaceous Lameta Formation, Narmada Basin, central India. Journal of Palaeogeography, 7(2), 99-116 (2018)

7. Bornhold, B. D., \& Giresse, P. Glauconitic sediments on the continental shelf off Vancouver Island, British Columbia, Canada. Journal of Sedimentary Research, 55(5), 653-664 (1985)

8. Huggett, J. M., \& Cuadros, J. Glauconite formation in lacustrine/palaeosol sediments, Isle of Wight (Hampshire Basin), UK. Clay Minerals, 45(1), 3549. (2010)

9. Huggett, J. M., Petroclays, H., Time, I., Space, I., Dating, A., \& Illit, F. Minerals: Glauconites and Green Clays. Reference Module in Earth Systems and Environmental Sciences; Elsevier: Amsterdam, The Netherlands (2013)

10. López-Quirós, A., Escutia, C., Sánchez-Navas, A., Nieto, F., Garcia-Casco, A., Martín-Algarra, A., ... \& Salabarnada, A. Glaucony authigenesis, maturity and alteration in the Weddell Sea: An indicator of paleoenvironmental conditions before the onset of Antarctic glaciation. Scientific reports, 9(1), 1-12 (2019)

11. McCaffrey, R. Global frequency of magnitude 9 earthquakes. Geology, 36(3), 263-266 (2008)

12. McConchie, D. M., Ward, J. B., McCann, V. H., \& Lewis, D. W. A Mössbauer investigation of glauconite and its geological significance. Clays and Clay Minerals, 27(5), 339-348 (1979)

13. Meunier, A., \& El Albani, A. The glauconite-Feillit-Fe-smektit problem: a critical review. Terra Nova, 19(2), 95-104 (2007)

14. Odin, G. S., \& Fullagar, P. D. Chapter C4 geological significance of the glaucony facies. In Developments in sedimentology (Vol. 45, pp. 295332). Elsevier (1988)

15. Odin, G. S., \& Matter, A. De glauconiarum origine. Sedimentology, 28(5), 611-641. (1981)

16. Putra, P. S., Yulianto, E., Praptisih, P., Supriatna, N., Trisuksmono, D., Amar, A., ... \& Griffin, J. STUDI PALEOTSUNAMI DI SELATAN JAWA PALEOTSUNAMI STUDY IN THE SOUTH COAST OF JAWA. PROSIDING GEOTEKNOLOGI LIPI (2015)

17. Pryor, W. A. Biogenic sedimentation and alteration of argillaceous sediments in shallow marine environments. Geological Society of America Bulletin, 86(9), 1244-1254 (1975)

18. Smaill, J. B. Geochemical variations in glauconitic minerals: application as a potassium fertiliser resource. (2015)
19. Sudana, D. \& Santosa, S. Geology of the Cikarang Quadrangle, Java: Pusat Penelitian dan Pengembangan Geologi, Bandung, 13 (1992)

20. Sujanto, F. X. dan Sumantri, Y. R. Preliminary Study on the Tertiary Depositional Patterns of Java. Bulletin of Scientific Contribution, Volume 13, Nomor 3. Desember 2015: 182-191. (1977)

21. Zulkarnain, D. A., Amijaya, H., \& Yulianto, E. Karakteristik Endapan Paleotsunami Di Pesisir Wanasalam, Daerah Wanasalam, Banten. In Proceeding, Seminar Nasional Kebumian Ke-10 Peran Penelitian Ilmu Kebumian Dalam Pembangunan Infrastruktur Di Indonesia 13-14 September 2017; Graha Sabha Pramana (2017) 